АТОМНА ЕНЕРГЕТИКА ATOMIC ENERGY

УДК 061.39

https://doi.org/10.15407/jnpae2019.04.381

\author{
V. I. Borysenko ${ }^{1}$, , D. V. Budyk ${ }^{2}$, V. V. Goranchuk ${ }^{1}$ \\ ${ }^{1}$ Institute for Safety Problems of Nuclear Power Plants, National Academy of Sciences of Ukraine, Kyiv, Ukraine \\ ${ }^{2}$ Private Joint-Stock Company "Severodonetsk Research and Production Association "Impulse", \\ Severodonetsk, Ukraine
}

*Corresponding author: vborysenko@ispnpp.kiev.ua

\title{
IMPROVING THE ACCURACY OF THERMAL POWER DETERMINATION OF VVER
}

In most algorithms for forming control signals, locks and protection of VVER, the value of the reactor's thermal power (RTP) is used. This article is dedicated to the analysis of the problem of determining the RTP of VVER-1000. The article suggests ways to improve the accuracy of the determination of RTP based on the signals of the neutron flux parameters control system at VVER-1000. The thermal power of the reactor is one of the important safety parameters of VVER-1000, and also this parameter determines the technical and economic parameters of the power unit. The task of increasing the accuracy of RTP determination is especially relevant considering plans to increase RTP of VVER-1000: in the first stage to $101.5 \%$ of the nominal value, and later to $104-107 \%$ of the nominal value, which equals to $3000 \mathrm{MW}$ according to the project. In the article, the main factors influencing the errors of determination of RTP in different ways are considered: according to the thermal parameters of the 1st and 2nd contours and the parameters of the neutron flux in the Neutron Flux Monitoring System (NFMS) and In-core Monitoring System (ICMS). In order to improve the accuracy of determination of RTP in the NFMS, we propose a model that considers the influence on the signal of the ionization chamber of the following parameters: temperature and concentration of boric acid in the coolant, the position of the control rods, burning of fuel, etc. The results of the analysis of the change in RTP during the fuel campaign of VVER-1000 are given, which is determined in different ways.

Keywords: reactor thermal power, thermal engineering parameters, neutron flux parameters, correction model, linear heat generation rate, weight coefficients.

\section{Introduction}

Reactor thermal power (RTP) is one of the most important parameters by which control and regulation at VVER-1000 are being carried out. On the basis of RTP values, algorithms of the following systems are implemented: automatic power controller (APC), power reducing/limiting device (PRLD); as well as preventive protection (PP), accelerated unit unloading (AUU) and emergency protection (EP) systems [1]. In addition, RTP is a parameter by which technical and economic indicators of a power unit are determined, including the coefficient of efficiency.

Correct determination of RTP (absolute value, error et al.) becomes more important at the implementation of plans to increase VVER-1000 thermal power to $104-107 \% \mathrm{~N}_{\text {rated }}$ (rated power), which equals $3000 \mathrm{MW}$ according to the project.

The methods of RTP determination applied today at various VVER-1000 are different; besides, the method of minimizing the error of RTP determination is not used.

Therefore, it is important to study the peculiarities of the determination of RTP by different methods at power levels, as well as to develop methods to reduce the error of the determination of so-called weighted mean thermal power (WMTP), which is determined on the basis of RTP data obtained in different methods.

\section{The methods of RTP determination}

The following methods are used to determine the RTP at VVER-1000 [2]:

1) by parameters of the 1 st circuit;

2) by parameters of the 2 nd circuit - by parameters of steam and feedwater flow rate in the steam generator (SG);

3) by parameters of the 2 nd circuit - by parameters of steam and feedwater flow rate in the highpressure heater (HPH);

4) by signals of the neutron flux monitoring system (NFMS);

5) by signals of self-powered neutron detectors (SPND).

Determination and control of RTP at VVER is carried out by the in-core monitoring system (ICMS) [2]. RTP at VVER-1000 is determined by $4 \div 5 \mathrm{me}-$ thods depending on the equipping of the power unit with control systems [3, 4].

Each of the methods for determining RTP is characterized by a corresponding error, which, in turn, depends on the errors in determining the RTP parameters.

The value of WMTP $N_{\text {mean }}$ and the error of its determination $\delta N_{\text {mean }}$ are calculated taking into account the weight coefficient $w_{i}$ of each method of RTP $N_{i}$ determination [5]:

(C) V. I. Borysenko, D. V. Budyk, V. V. Goranchuk, 2019 


$$
\begin{gathered}
N_{\text {mean }}=\frac{\sum_{i=1}^{N} w_{i} \cdot N_{i}}{\sum_{i=1}^{N} w_{i}}, \\
\delta N_{\text {mean }}=\frac{\sqrt{\sum_{i=1}^{N}\left(w_{i} \cdot \delta N_{i}\right)^{2}}}{\sum_{i=1}^{N} w_{i}},
\end{gathered}
$$

where $\delta N_{i}$ is the error of RTP determination by the i-th method.

On VVER-1000 units use different sets of values of the weight coefficients $w_{i}$, which is why the task of implementing the methodology of optimal choice of weight coefficients is urgent.

Improving the accuracy of the RTP determination in a separate method, as well as the correct determination of the weight coefficient of the contribution of each method of RTP determination in the reactor WMTP allows minimizing the error of WMTP determination.

The components of the error of WMTP determination are the following:

systematic error, which in turn consists of method and hardware errors of WMTP determination;

dynamic error, which is determined by the response time of the method and can be significant in non-stationary processes;

random error, which is determined by the RTP level and the state of measuring channels.

Consider the features of the RTP determination by each of the methods used in VVER-1000.

1. RTP determination by parameters of the 1 st circuit.

RTP by parameters of the 1 st circuit is determined as the sum of the thermal powers of all operating loops (in VVER-1000 there are four of them), taking into account the heat losses on the equipment of the 1st circuit. In turn, the thermal power of the $\mathrm{i}$-th operating loop is determined as:

$$
N_{1, i}=G_{i} \cdot\left(I_{h}-I_{g}\right)
$$

where $G_{i}$ - the coolant flow rate in the i-th loop, $\mathrm{kg} / \mathrm{s}$; $I_{h}, I_{g}$ - the coolant enthalpy in hot and cold legs, respectively, J/kg.

The error in RTP determination by parameters of the 1st circuit depends on:

error of determination of the coolant flow rate through the loop on the basis of the head vs. flow rate characteristic (HFC) of the main circulation pump (MCP), which in turn is determined by the difference between the actual scheme of measurement of pressure difference on the MCP, from the bench scheme at the MCP manufacturer; and accuracy of determination of the coolant temperature of the cold leg from which the density of the coolant is determined;

error in determining the coolant enthalpy, which depends on the accuracy of determination of coolant pressure and temperature in the hot and cold legs, and the accuracy of the approximating dependencies of the enthalpy on pressure and temperature.

The accuracy of the RTP determination by parameters of the 1 st circuit is significantly affected by the accuracy of coolant temperature determination in the hot leg. This is a consequence of the hydrodynamic features of the coolant in the hot leg, namely the coolant stratification. It is the coolant stratification that leads to the fact that the difference in temperature values from the temperature control sensors in the hot leg can reach $\sim 3^{\circ} \mathrm{C}$ and more [6], which increases the error of determination of the loop power to more than $10 \%$.

Taking into account the differences in the location of temperature control sensors in the hot legs of different VVER-1000, as well as the dependence of the intensity of coolant stratification on the reactor power, the number of operating loops, etc., the error in the RTP determination by parameters of the $1 \mathrm{st}$ circuit of VVER-1000 is a feature of each individual VVER-1000 and should be further studied.

Respectively weight coefficient of a contribution of RTP by parameters of the 1 st circuit in WMTP determination depends on the power level, number of operating loops, etc.

Therefore, additional investigations at the object should be conducted for the correct determination of systematic error (methodical) of RTP calculation.

The error of temperature determination of the $1 \mathrm{st}$ circuit coolant was reduced during the modernization of ICMS due to use of individual more highaccuracy analog-to-digital converter (ADC), an increase of sampling frequency of sensors as well as the use of individual calibrating characteristics of thermocouples (TC) and resistance thermometers (RT). Such measures allowed to reduce absolute error in temperature determination from $1{ }^{\circ} \mathrm{C}$ to $\pm(0,1 \div 0,2) \quad{ }^{\circ} \mathrm{C}[3]$.

Switching to the use of more up-to-date data, such as tables of properties of water and steam, is also justified [7, 8].

In case of the insignificant influence of stratification on a determination of the coolant temperature in the hot leg, determination of coolant flow rate through the loop introduces the biggest error in RTP determination by parameters of the 1 st circuit.

For determination of dynamic error in RTP determination it is necessary to take into account coolant transit time between points of temperature measurement in cold and hot legs, which can be from 3 to $6 \mathrm{~s}$, depending on a number of operating loops [3].

It is also necessary to take into account that in case of TC change to more accurate RT, a dynamic error will be increased due to greater response time of RT compared to TC. 
2. RTP determination by parameters of the 2 nd circuit - by parameters of steam and feedwater flow rate in the SG.

RTP by parameters of the 2 nd circuit (SG) is determined as a sum of the thermal powers of all working SG, taking into account the heat losses on the equipment of the 1 st and the 2 nd circuits. In turn, the thermal power of the $\mathrm{i}$-th operating SG $N_{2 S G, i}$ is determined as

$$
N_{2 S G, i}=N_{i}^{s t}+N_{i}^{\text {purge }}-N_{i}^{f w}-N_{i}^{M P},
$$

where $\quad N_{i}^{s t}=G_{i}^{s t} \cdot\left(I_{i}^{\prime} \cdot x+I_{i}^{\prime \prime} \cdot(1-x)\right) \quad-\quad$ power, which is removed by steam from $\mathrm{SG}, \mathrm{W}$; $N_{i}^{\text {purge }}=G_{i}^{\text {purge }} \cdot I_{i}^{\prime}-$ power, which is removed by blowdown water from SG, W; $N_{i}^{f w}=G_{i}^{f w} \cdot I_{i}^{f w}$ power, which is applied by feedwater in SG, W; $N_{i}^{M P}$ - power, which is applied in the reactor from MCP, W; $G_{i}^{\text {st }}$ - steam flow rate in i-th $\mathrm{SG}, \mathrm{kg} / \mathrm{s}$; $G_{i}^{\text {purge }}-$ blowdown water flow rate in i-th $\mathrm{SG}, \mathrm{kg} / \mathrm{s}$; $G_{i}^{f w}$ - feedwater flow rate in i-th SG, kg/s; $I_{i}^{\prime}, I_{i}^{\prime \prime}-$ water enthalpy on saturation line in SG and steam enthalpy at the output from SG, accordingly, J/kg; $I_{i}^{f w}$ - feedwater enthalpy in $\mathrm{i}$-th $\mathrm{SG}, \mathrm{J} / \mathrm{kg} ; x-$ degree of steam moisture.

The error of RTP determination by parameters of the 2nd circuit (SG) depends on:

errors in the determination of the steam and water enthalpy on the saturation line in SG and feedwater enthalpy to SG, which, in turn, are determined by errors in measurement of corresponding temperatures and pressures;

errors in the determination of steam flow rate in $\mathrm{SG}$, feedwater, and blowdown water flow rates.

However, in the most of VVER-1000 projects, direct measurements of steam flow rate from SG aren't realized, and hence this parameter is determined from material balance equation, namely feedwater flow rate will be equal to steam flow rate from SG and blowdown water flow rate only in case of a constant level in SG. In practice, the level regulator in SG is working constantly, so it is necessary to take into account additional components in the material balance equation. Therefore, at WMTP determination, the weight coefficient of RTP value determined by the parameters of the 2 nd circuit (SG) will also depend on the operating conditions and power level of a reactor plant (RP). The error of RTP determination by parameters of the 2 nd circuit (SG) will be the lowest when VVER-1000 works at the power levels close to the nominal [4].

For stationary operating conditions of VVER1000 , the biggest contribution in the error of RTP determination gives an error of determination of the feedwater flow rate.

For determination of dynamic error in RTP determination by parameters of the 2 nd circuit (SG) it is necessary to take into account coolant transit time from point of feedwater temperature measurement to the entry point in SG, which can reach $\sim 20 \div 30$ s and depends on the feedwater supply scheme at the specific VVER-1000 [3, 4].

3. RTP determination by parameters of the 2 nd circuit - by parameters of steam and feedwater flow rate in the $\mathrm{HPH}$.

RTP by parameters of the 2nd circuit (HPH) is determined as a sum of thermal powers of all working HPH (there are two of them in VVER-1000), taking into account heat loss on the equipment of the 1 st and 2 nd circuit.

Thus, Eq. (4) will have the following form:

$$
\begin{aligned}
N_{2 H P, i}= & 0.5 \cdot N_{j}^{H P}+N_{i}^{\text {purge }}-N_{i}^{f w}-N_{i}^{M P}, \\
N_{2 H P, i}= & \left(0,5 \cdot G_{j}^{H P}-G_{i}^{\text {purge }}\right) \cdot\left(I_{i}^{\prime \prime}-I_{j}^{H P}\right)+ \\
& +G_{i}^{\text {purge }}\left(I_{i}^{\prime}-I_{j}^{H P}\right)-N_{i}^{M P},
\end{aligned}
$$

where $G_{j}^{H P}$ - feedwater flow rate through j-th $\mathrm{HPH}$, $\mathrm{kg} / \mathrm{s} ; j=1,2 ; I_{j}^{H P}-$ water enthalpy at the output from $\mathrm{j}$-th $\mathrm{HPH}, \mathrm{J} / \mathrm{kg}$.

HPH with $j=1$ is related to SG with $i=1,2$, and HPH with $j=2$ is related to SG with $i=3,4$.

The error in RTP determination by parameters of the 2nd circuit (HPH) depends on:

errors in the determination of the steam and water enthalpy on the saturation line in SG and feedwater enthalpy in HPH, which, in turn, are determined by errors in measurement of corresponding temperatures and pressures;

errors in determination of steam flow rate in SG, feedwater flow rate in HPH and blowdown water flow rate.

Therefore, the problem in error determination in the measurement of water flow rate before HPH is added to the listed above problems of error determination with the use of the SG method.

Method of RTP determination by the parameters of the 2nd circuit (HPH) is not used at some units with VVER-1000 (for example, Bushehr NPP, Tianwan NPP) due to peculiarities in the determination of corresponding thermal and technical parameters $[3,4,9]$.

4. RTP determination by signals of NFMS.

RTP by signals of NFMS $\mathrm{N}_{\mathrm{IC}}$ is determined as a sum of signals of all NFMS control channels (CC) which is normalized to the number of $\mathrm{CC}$. The peculiarity of NFMS is that the neutron-flux density, 
which determines reactor neutron power, is not determined directly but coefficient is determined for every ionization chamber (IC) of NFMS CC during so-called calibration as a value by which it is necessary to multiply IC signal value to receive value of thermal power (in W) at which NFMS calibration is carried out. However, this approach is justified and provides the necessary accuracy of power determination only for the operating modes with a constant power distribution profile over the core volume.

The issue is that during transient modes of VVER with change of such parameters as coolant temperature at reactor inlet; boric acid concentration in coolant of the 1st circuit; pressure in the 1st circuit; movement of control rods of reactor control and safety system (CR RCSS); as well as nuclear fuel burn-up changes neutron distribution over the reactor core volume, which, in turn, influences on leakage of neutrons from the reactor core, that are registered by NFMS IC [10].

To establish the correspondence between reactor neutron power and the signal of NFMS IC, a regular calibration procedure is performed, which provides necessary accuracy in the determination of neutron power in NFMS (according to the VVER-1000 project, the error is not more than $2 \%$ ). Correspondence between reactor neutron power and the signal of NFMS IC remains for some time $(\sim 7 \div 10$ days $)$ during the steady-state operation of the reactor. During transient modes of reactor operation, established during calibration correspondence becomes broken, which leads to the increase in neutron power determination error that can essentially exceed a $2 \%$ limit, which is set by Standard operating procedure of VVER-1000 safe operation [11].

To solve such a problem, it is necessary to develop the model of NFMS operation, which would take into account the influence of change in reactor technological parameters on NFMS IC signals and properly correct them.

Modern design codes should be used for the development of such NFMS model, which should be built on the use of the Monte-Carlo method for simulation of neutron transport in the core, near vessel space of VVER and in places of IC location in the concrete of reactor biological shielding.

It was confirmed previously [10] that implementation of correction of NFMS IC signals will allow providing regulatory requirements concerning the error in reactor neutron power determination, namely - not more than $2 \%$, for the wide range of transient modes of RP operation, including during power maneuvering.

The introduction of correction in the NFMS will increase the safety of operation of VVER by ensuring the correct determination of the neutron power of the reactor, and, accordingly, the projective formation of protection and blocking signals for external systems, including RCSS.

5. RTP determination by signals of SPNDs in ICMS.

RTP determination by signals of SPNDs is realized in ICMS through the estimation of the linear heat generation rate (LHGR) of the fuel assembly (FA) in the locations of SPNDs.

LHGR of FA in the locations of SPNDs is determined by the equation $[2,10]$ :

$$
q_{n m}=a_{n m}\left(Y_{n m}-Y_{n m}^{F}\right),
$$

where $Y_{n m}$ - current of $m$-th SPND in n-th neutron flux measuring channel (NFMC); $Y_{n m}^{F}$ - background current; $a_{n m}$ - coefficient, which depends on the parameters of the core in the location of the SPND, namely: enrichment and burn-up of the fuel, temperature, and pressure of the coolant, the concentration of boric acid in the coolant of the 1 st circuit, the burning of the fuel emitter.

RTP by signals of SPNDs is determined by the equation:

$$
N_{S P N D}=K \cdot \sum_{n=1}^{N} \sum_{m=1}^{M} q_{n m} \cdot h
$$

where $K$ - a coefficient that takes into account relation between the power in the whole core and the power in the prisms with SPNDs, and which is determined by the ratio of average linear power in the core to the average linear power in (NxM) prisms with SPNDs; $h$-height of the prism with SPND.

The biggest error in the RTP determination by signals of SPNDs is the uncertainty of the coefficient $a_{n m}$, which is calculated separately for each fuel type in the ICMS.

However, the ICMS still uses the algorithm for calculating $a_{n m}$ coefficients based on simplified models of more than 30 years old, which incorrectly takes into account the influence of such factors as $[10,12]$ :

spectral factor, which takes into account the change in the neutron spectrum as a result of fuel burn-up, changes in the concentration of boric acid in the coolant of the 1st circuit, change in the coolant temperature at the location of the SPND;

geometric factor; since the SPND signal is generated by the neutrons of the adjacent fuel assemblies by $25-30 \%$, it is necessary to calculate the $a_{n m}$ coefficients not only for each fuel type but also for the actual loading of the fuel campaign in order to take into account the influence of neutrons of adjacent fuel assemblies on the SPND signal; 
SPND burn-up factor, which is determined by a decrease in the probability that electrons will fly from the emitter to the collector of the detector, due to the greater burn-up of outer layers of SPND.

When determining the RTP on the basis of SPND signals, it is also necessary to take into account the possible vertical shift of the SPND position from the design one.

Table 1 shows data from [9] concerning the error of RTP determination by different methods on VVER-1000. As has been already noted, the errors of RTP determination depend on many factors and they should be determined separately for each VVER1000 and depending on the mode of operation of RP. However, for a long time, the weight coefficients $w_{i}$ were equal to $1\left(\right.$ and/or $\left.w_{j}=0\right)$ in the calculation of the WMTP in the ICMS, regardless of the operating mode and power of the VVER-1000 [13].

\section{Table 1. Errors of VVER-1000 RTP determination [9]}

\begin{tabular}{|c|c|c|c|c|c|}
\hline $\begin{array}{c}\text { Method of RTP } \\
\text { determination }\end{array}$ & $\mathrm{N}_{1}$ & $\mathrm{~N}_{2 \mathrm{SG}}$ & $\mathrm{N}_{2 \mathrm{HP}}$ & $\mathrm{N}_{\mathrm{SPND}}$ & $\mathrm{N}_{\mathrm{IC}}$ \\
\hline Relative error, \% & 5.1 & 1.1 & 1.5 & 4.5 & 2.9 \\
\hline
\end{tabular}

Table 2 shows data on the weight coefficients as well as the results of the calculation of the WMTP error for various VVER-1000 power units and for various fuel campaigns [13]. The error of the RTP determination by a separate method was taken according to Table 1, in order to carry out such estimation.

Table 2. Weight coefficients $w_{i}$ for VVER-1000 WMTP determination [13]

\begin{tabular}{|l|c|c|c|c|c|c|c|c|c|c|c|c|}
\hline Method & \multicolumn{3}{|c|}{ K5(13- 22)* } & \multicolumn{4}{|c|}{ K6(12-20) } & \multicolumn{3}{c|}{ T1(1-9) } & T2(1-7) & $\mathrm{X} 1$ \\
\hline $\mathrm{N}_{1 \mathrm{k}}$ & 1.00 & 1.00 & 0.66 & 1.00 & 1.00 & 1.00 & 0.32 & 0.91 & 0.91 & 0.63 & 0.64 & 0.500 \\
\hline $\mathrm{N}_{2 \mathrm{SG}}$ & 1.00 & 1.00 & 1.00 & 1.00 & 1.00 & 1.00 & 1.00 & 1.00 & 1.00 & 1.00 & 1.00 & 1.000 \\
\hline $\mathrm{N}_{2 \mathrm{HP}}$ & 1.00 & 1.00 & 1.00 & 1.00 & 1.00 & 0.56 & 1.00 & 0.00 & 0.00 & 0.00 & 0.00 & 0.475 \\
\hline $\mathrm{N}_{\text {SPND }}$ & 0.00 & 1.00 & 0.36 & 0.00 & 1.00 & 0.00 & 0.90 & 0.53 & 0.00 & 0.42 & 0.47 & 0.115 \\
\hline $\mathrm{N}_{\mathrm{IC}}$ & 0.00 & 0.00 & 0.00 & 0.00 & 0.00 & 0.00 & 0.00 & 0.50 & 0.50 & 0.51 & 0.58 & 0.100 \\
\hline$\delta, \%$ & 1.81 & 1.76 & 1.38 & 1.81 & 1.76 & 2.06 & 1.47 & 1.88 & 2.07 & 1.62 & 1.63 & 1.34 \\
\hline
\end{tabular}

* An(k1-k2) denotes: A - the name of NPP (K - Kozloduy NPP, T - Tianwan NPP, X - Khmelnytskyi NPP); $\mathrm{n}$ - unit number; $\mathrm{k} 1, \mathrm{k} 2$ - fuel campaign numbers; $\delta$ - relative error.

Table 3 shows data on the range of changes in weight coefficients of every method of RTP determination, in the condition of normalization on 1,0 of the sum of all weight coefficients.

Table 3. Range of changes in weight coefficients $\boldsymbol{w}_{i}$

\begin{tabular}{|l|c|c|c|}
\hline Method & Min & Max & Average \\
\hline $\mathrm{N}_{1}$ & 0.099 & 0.391 & 0.269 \\
\hline $\mathrm{N}_{2 \text { SG }}$ & 0.250 & 0.457 & 0.349 \\
\hline $\mathrm{N}_{2 \mathrm{HP}}$ & 0.000 & 0.333 & 0.184 \\
\hline $\mathrm{N}_{\text {SPND }}$ & 0.000 & 0.280 & 0.125 \\
\hline $\mathrm{N}_{\mathrm{IC}}$ & 0.000 & 0.216 & 0.075 \\
\hline
\end{tabular}

As can be seen from the given data (Tables 2 and 3 ), different weight coefficients $w_{i}$ are used at different VVER-1000 units for taking into account RTP values in WMTP. Apparently, reduction of error in WMTP determination can be achieved in the following cases: reduction of the error in RTP determination by separate methods; choice of optimal weight coefficients $w_{i}$; application of additional independent methods for RTP determination.

\section{Conclusions}

Minimization of the error of the weighted mean value determination is a classical problem that has been already solved theoretically. However, the task of the minimization of the error in WMTP determination is not yet solved at any of the considered power units. Therefore, it is important to conduct additional investigations dedicated to minimization of the error in WMTP determination at VVER-1000.

The article presents suggestions to improve the accuracy of the RTP determination separately by each of the methods of RTP determination and considers the way to minimize the error of WMTP determination. The main attention was focused on improving the accuracy of RTP determination in NFMS and ICMS. In order to increase the accuracy of RTP determination in these systems, the authors proposed scientific and technical solutions obtained in the course of development of applied software for modern NFMS and ICMS, which are supplied to NPP units with VVER-1000 in Ukraine.

\section{REFERENCES}

1. Neutron Flux Control Equipment. Specifications. TU U 30.0-31393258-010-2003 A. (Rus)

2. V.A. Bragin et al. In-core Monitoring Systems of NPP with VVER (Moskva: Energoatomizdat, 1987) 128 p. (Rus)
3. A.N. Dobrotvorskii. Development and substantiation of methods of determination of weighted mean power of NPP units with VVER-1000. The thesis of the Candidate of Technical Sciences. (Novovoronezh, 2017) 191 p. (Rus) 
4. Yu.V. Saunin, A.N. Dobrotvorskii, A.V. Semenikhin. Methods of Estimation of Weight Coefficient when Determining Weighted Mean Thermal Power of VVER Reactors. Tyazheloe Mashinostroenie (August 2008). (Rus)

5. J. Taylor. An Introduction to Error Analysis: The Study of Uncertainties in Physical Measurements. 2nd edition (United States, Sausalito: University Science Books, 1997) 327 p.

6. V.F. Bai et al. State of in-core thermal control and analysis of the main thermal and physical characteristics of RP of Kalinin NP. In: Book of Abstracts of the $7^{\text {th }}$ Intern. Sci. and Technical Conf. "Safety, Effectiveness, and Economics of Nuclear Power Engineering”, Moskva, Russia, 2020, p. 228. (Rus)

7. M.P. Vukalovich. Thermophysical Properties of Water and Steam (Moskva: Mashinostroenie, 1967) 160 p. (Rus)

8. A.A. Aleksandrov, B.A. Grigor'ev. Tables of Thermophysical Properties of Water and Steam (Moskva: Publishing house of MEI, 1999) 168 p. (Rus)

9. Yu.V. Saunin et al. Possibilities of operative evalua- tions of weight coefficients of weighted mean thermal power of VVER reactors. In: Proc. of the Conf. "Safety Assurance at NPP with VVER", OKB "Gidropress", May 26 - 29, 2009. (Rus)

10. V.I. Borysenko. Enhancement of methods and means for operational control and diagnostics of neutronic parameters of nuclear installations. The thesis of Doctor of Technical Sciences (Kyiv, 2018) 400 p. (Ukr)

11. Standard operating procedure of Rivne NPP $4^{\text {th }}$ unit safe operation. 4-RNPP. (Rus)

12. V.I. Borysenko, Yu. F. Piontkovskyi, V.V. Goranchuk. An investigation of models of rhodium emitter used in a self-powered neutron detector. Problemy Bezpeky Atomnykh Elektrostantsiy i Chornobylya (Problems of Nuclear Power Plants' Safety and of Chornobyl) 28 (2017) 16. (Rus)

13. D.V. Vorob'eva et al. Calculation of RP capacity on parameters of in-core detectors. Analysis of operation experience. In: Book of Abstracts. $10^{\text {th }}$ Intern. Sci. and Technical Conf. "Safety Assurance at NPP with VVER", Podolsk, 2017. (Rus)

\title{
В. І. Борисенко ${ }^{1, *}$, Д. В. Будик², В. В. Горанчук ${ }^{1}$ \\ ${ }^{1}$ Інститут проблем безпеки АЕС НАН Украӥни, Київ, Украӥна \\ ${ }^{2}$ ПрАТ Сєвєродонецьке НВО «ІМПУЛЬС», Сєвєродонецььк, Украйна \\ *Відповідальний автор: vborysenko@ispnpp.kiev.ua \\ ПІДВИЩЕННЯ ТОЧНОСТІ ВИЗНАЧЕННЯ ТЕПЛОВОЇ ПОТУЖНОСТІ ВВЕР
}

У більшості алгоритмів формування сигналів керування, блокувань і захистів ВВЕР використовується значення теплової потужності реактора (ТПР). Стаття саме призначена аналізу задачі визначення ТПР ВВЕР-1000. Запропоновано способи підвищення точності визначення ТПР на основі сигналів систем контролю параметрів нейтронного потоку на ВВЕР-1000. ТПР є одними з важливих параметрів безпеки ВВЕР-1000, а також за цим параметром визначаються техніко-економічні показники енергоблока. Задача підвищення точності визначення ТПР $є$ актуальною особливо з огляду на плани з підвищення ТПР ВВЕР-1000: на першому етапі до 101,5\% номінальної, а пізніше і до 104 - 107 \% номінальної, яка згідно з проектом становить 3000 МВт. Розглянуто основні фактори, що впливають на похибки визначення ТПР різними способами: за теплотехнічними параметрами 1-го та 2-го контурів і за параметрами нейтронного потоку в апаратурі контролю нейтронного потоку (АКНП) і системі внутрішньореакторного контролю. Для підвищення точності визначення ТПР в АКНП запропоновано модель врахування впливу на сигнал іонізаційної камери зміни таких параметрів: температура і концентрація борної кислоти в теплоносії, положення органів регулювання системи управління і захисту, вигоряння палива тощо. Наведено результати аналізу зміни ТПР протягом паливної кампанії ВВЕР-1000, яку визначено різними способами.

Ключові слова: теплова потужність реактора, теплотехнічні параметри, параметри нейтронного потоку, модель корекції, лінійне енерговиділення, вагові коефіцієнти.

\author{
В. И. Борисенко ${ }^{1, *}$, Д. В. Будик ${ }^{2}$, В. В. Горанчук ${ }^{1}$ \\ ${ }^{1}$ Институт проблем безопасности АЭС НАН Украины, Киев, Украина \\ ${ }^{2}$ ЧАО Северодонеџкое НПО «ИМПУЛЬС», Северодонеџк, Украина \\ *Ответственный автор: vborysenko@ispnpp.kiev.ua
}

\section{ПОВЫШЕНИЕ ТОЧНОСТИ ОПРЕДЕЛЕНИЯ ТЕПЛОВОЙ МОЩНОСТИ ВВЭР}

В большинстве алгоритмов формирования сигналов управления, блокировок и защит ВВЭР используется значение тепловой мощности реактора (ТМР). В статье проведен анализ задачи определения ТМР ВВЭР-1000, 
предложены способы повышения точности определения ТМР на основе сигналов систем контроля параметров нейтронного потока на ВВЭР-1000. ТМР является одним из важных параметров безопасности ВВЭР-1000, а также по этому параметру определяются технико-экономические показатели энергоблока. Задача повышения точности определения ТМР актуальна, особенно учитывая планы по повышению ТМР ВВЭР-1000: на первом этапе до 101,5 \% номинальной, а позже и до 104 - 107 \% номинальной, которая согласно проекту составляет 3000 МВт. Рассмотрены основные факторы, влияющие на погрешности определения ТМР различными способами: по теплотехническим параметрам 1-го и 2-го контуров, по параметрам нейтронного потока в аппаратуре контроля нейтронного потока (АКНП) и в системе внутриреакторного контроля. Для повышения точности определения ТМР в АКНП предложена модель учета влияния на сигнал ионизационной камеры изменения таких параметров: температура и концентрация борной кислоты в теплоносителе, положения органов регулирования системы управления и защиты, выгорания топлива и др. Приведены результаты анализа изменения ТМР, определенной различными способами, в течение топливной кампании ВВЭР-1000.

Ключевые слова: тепловая мощность реактора, теплотехнические параметры, параметры нейтронного потока, модель коррекции, линейное энерговыделение, весовые коэффициенты. 